\title{
Factors Affecting Students' Academic Performance in Higher Education: Evidence from Accountancy Degree Programme
}

\author{
Haslinda Hassan ${ }^{\mathrm{a}}$, Rosli Mohamad ${ }^{\mathrm{b}}$, Raja Haslinda Raja Mohd Ali ${ }^{\mathrm{c}}$, Yurita Yakimin Abdul Talib ${ }^{\mathrm{d}}$, Hafizah \\ Mohamad Hsbollah ${ }^{\mathrm{e}}$ \\ ${ }^{a, b, c, d . e}$ Tunku Puteri Intan Safinaz School of Accountancy (TISSA-UUM), College of Business, Universiti Utara \\ Malaysia, Malaysia \\ Corresponding author: lynn@uum.edu.my
}

To cite this article (APA): Hassan, H., Mohamad, R., Raja Mohd Ali, R. H., Abdul Talib, Y. Y., \& Mohamad Hsbollah, H. (2020). Factors Affecting Students' Academic Performance in Higher Education: Evidence from Accountancy Degree Programme. International Business Education Journal, 13(1), 1-16. https://doi.org/10.37134/ibej.vol13.1.1.2020

To link to this article: https://doi.org/10.37134/ibej.vol13.1.1.2020

\begin{abstract}
The increasing demands for accountants in the future have resulted in an increased number of students enrolling in the accounting programmes of Malaysian universities. This expansion, however, has caused some concern about whether these students are likely to succeed in their studies. This study, therefore, aims to examine the factors that drive the academic performance of accounting students at Malaysian universities. The factors included gender, ethnic groups, type of secondary school, sponsorship, and family income. The students' academic performance was represented by their cumulative grade point average (CGPA) obtained at the end of their programs. The study used a quantitative research design using secondary data of 367 undergraduate accounting students graduated in 2016 from the Universiti Utara Malaysia (UUM) for analysis. The findings suggested that there were significant differences in students' academic performance related to ethnic groups, type of secondary school, and family income. Specifically, Malay, Indian, and other students performed less well than did Chinese students. Gender and sponsorship, however, had no significant influence on their academic performance. The study's findings could help higher learning institutions, parents, and policymakers to formulate effective intervention mechanisms and to introduce a more holistic approach to improve student performance.
\end{abstract}

\section{Keywords:}

Academic performance, accounting students, undergraduate, CGPA, ethnicity, types of school, income

\section{INTRODUCTION}

Malaysia needs to double its accountants to 60,000 to support its transformation into a highincome nation by 2020 (NST Online, 2015). The increasing demands for accountants in the future has resulted in universities (be they public or private universities) offering an increasing number of accounting programmes, and the number of students enrolled in accounting programmes has continued to grow. For example, the findings of a 2015 study reported that $14 \%$ of the 123,947 graduates in 2015 had studied accounting, making it the second largest programme of choice after business administration (20.7\%) (MOHE, 2015). However, this expansion has caused some concern regarding whether students studying accounting are likely to encounter success in their studies. 
The issue of student performance at a university has been a major concern in prior studies. Many researchers have shown their interest in understanding the factors that influence the academic performance of the students in higher learning institutions. Many studies have attempted to establish a direct causal link between various factors and the performance of undergraduates. These include demographic characteristics, type of secondary school (e.g., high performance schools), and socio-economic factors. In this context, prior studies have highlighted that various factors impact academic performance, including gender (Ahmad, Pervaiz, \& Aleem, 2015; Alfan \& Othman, 2005; Ali \& Hayat, 2019; Azmi \& Mustapha, 2017), race or ethnic groups (Alfan \& Othman, 2005; Azmi \& Mustapha, 2017), type of secondary school (Kumwenda, Cleland, Walker, Lee, \& Greatrix, 2017), family income (Farooq, Chaudhry, Shafiq, \& Berhanu, 2011; Kamal \& Ahuja, 2019), parents qualification and background (Kamal \& Ahuja, 2019; Olufemioladebinu, Adediran, \& Oyediran, 2018), the number of school resources, and the condition of schools' facilities (Ali \& Hayat, 2019).

Despite a growing body of literature conducted in the area of students' academic performance, there remains significant variation on how any of these factors could affect academic performance in the context of Malaysian higher learning institutions. This is due to the mixed findings reported by the existing studies between the relationship of these factors and academic performance. As a result, the exact factors and how they could affect students' performance have not been fully examined, especially in the context of the students in Malaysian universities. The aim of this study is, therefore, to investigate the factors (i.e., gender, ethnic groups, type of secondary school, sponsorship, and family income) affecting student's academic performance at the tertiary education level. Understanding factors related to academic success and failure is particularly important as the intention of policy initiatives is not simply to inspire students to commence higher education study but to complete it satisfactorily (Byrne \& Flood, 2008). The findings of the study could help higher learning institutions, parents, and policymakers (be they at the state or federal level) to formulate effective intervention mechanisms and to introduce more holistic approaches in improving student performance. Comparing the academic performance of the different ethnic groups could also help determine why certain groups lag behind others.

The remainder of the article is set up as follows. First, the literature review on academic performance and its determinants are presented. The last two sections have a discussion of the empirical results of the study and a conclusion.

\section{LITERATURE REVIEW}

In Malaysia, education at the primary and secondary levels has been considered to be a crucial platform to mould young generation with the necessary knowledge, competencies, and skills that facilitate their survival in a highly competitive global economic environment. To reach this objective, the government has made several improvements in the educational system. Among others, the government has created the High Performance Schools Programme, which recognises schools that exhibit high performance based on Malaysian Education Quality Standards metrics. The aim of this programme is to produce outstanding students of international calibre to "enable them to pursue their studies in the best educational institutions in the world and to be exceptional personalities in all fields of endeavour" (https://moe.gov.my). These schools are amongst the preferred choice of the parents, together with a variety of boarding schools and junior science colleges (Maktab Rendah Sains Mara/MRSM). Besides, parents also have options to send their children to religious secondary schools, technical schools, national secondary schools, and vocational colleges. Given that 
both parents and students have various options for the selection of a secondary school, one concern is whether attending high performing schools or boarding schools could improve future student performance, especially at the university level.

Prior studies have identified demographic characteristics, type of secondary school, and socio-economic factor as possible determinants of students' academic performance at various level (e.g., schools and colleges). Nonetheless, the mixed results reported in these studies suggest insufficient support to reach a conclusion, especially for understanding student performance at the university level. Moreover, prior studies do not highlight the relationship of financial sponsorship and academic performance. Hence, the impact of these factors on academic performance is unclear.

To date, no single study has highlighted the impact of gender, ethnic groups, type of secondary school, sponsorship, and family income on students' academic performance attending Malaysian universities. This study, therefore, fills this gap by assessing the impact of these factors on academic performance amongst university students. Specifically, this study aims to investigate the extent to which a student's tertiary academic performance can be explained by gender, ethnic groups, type of secondary school, sponsorship, and family income.

In general terms, academic performance can be defined as the success of an individual in formal education in elementary, secondary, or tertiary education. However, the measurements being used for academic performance have been inconsistent across studies. Some studies have employed Grade Point Average (GPA) (Goff \& Ackerman, 1992), whereas other studies have used first-year examination scores (Ahmad et al., 2015), final year examination scores (Conard, 2006), or Cumulative Grade Point Average (CGPA) (Adzido, Dzogbede, Ahiave, \& Dorkpah, 2016; Ahmad et al., 2015; Alfan \& Othman, 2005). In this study, academic performance is proxied at the tertiary education level by the CGPA, which is calculated by dividing the total number of grade points earned by the total number of credit hours (Aidoo-Buameh \& Ayagre, 2013).

\section{RESEARCH MODEL AND HYPOTHESES}

This study incorporates the factors identified in the previous research as determinants of student academic performance. The research model of the study is illustrated in Figure 1. Five factors hypothesised to affect the academic performance of the students are gender, ethnicity, type of secondary school, the availability of education financial sponsorship, and family income.

With respect to gender, prior studies have shown interest in assessing the effect of gender differences on academic performance in elementary school, secondary school, high school, and university (Ahmad et al., 2015; Ghazvini \& Khajehpour, 2011; Ngozi, 2011; Lam et al., 2012). Lam et al. (2012), for instance, found that girl reported higher levels of engagement and rated higher academic performance as compared to boys in elementary schools from 12 countries across the world. While examining the CGPAs of high school students, Ghazvini and Khajehpour (2011) observed that female students achieved relatively higher scores than males in Literature with the female students are more adaptive to learning tasks. This trend is further confirmed at the university level. For example, Ngozi (2011) found that females lead males in arts-related subjects at university, and Ahmad et al. (2015) discovered that female students at Government College University, Lahore outperformed the 
male students. Other studies discovering that females outperformed males include Azmi and Mustapha (2017) and Farooq et al. (2011).

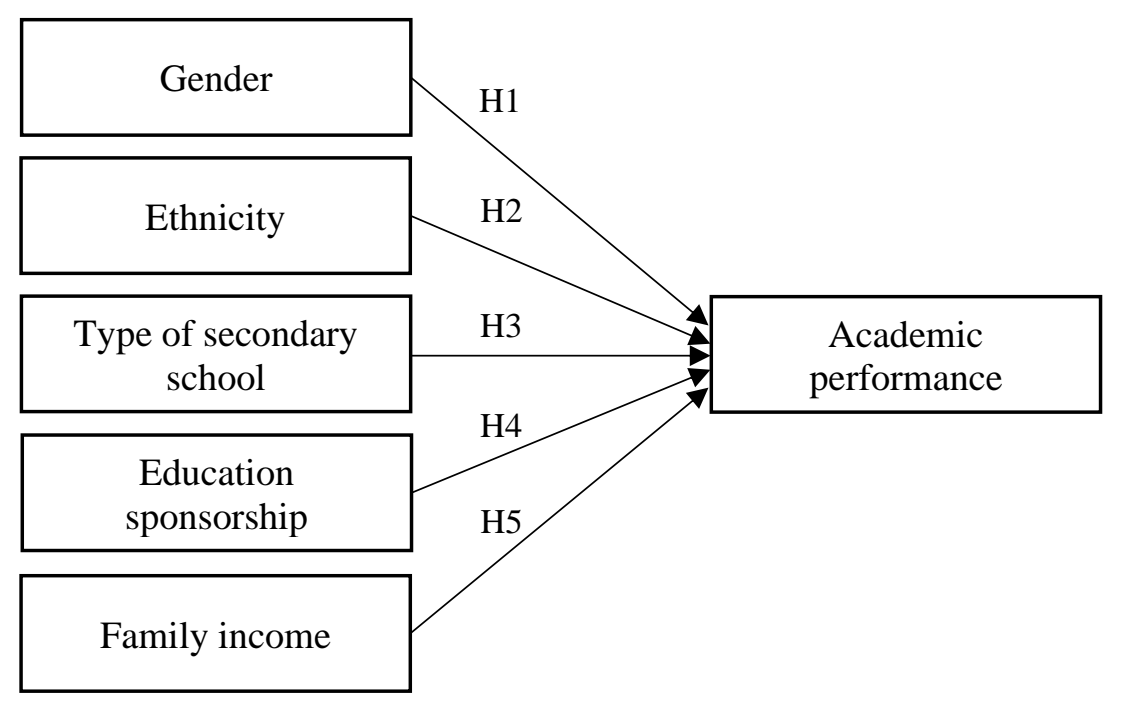

Figure 1: Research Model

Thus, a tendency exists for female students to beat male students academically from elementary school to their adolescence. This would suggest that female students are more serious and committed to ensuring better academic achievement. Hence, gender is seen as an important variable in predicting academic performance. Consequently, it is hypothesised that:

\section{H1 : Gender is related to academic performance.}

Ethnicity has been reported as one of the determining factors for varying academic performance. Malaysia is made up of $60 \%$ Bumiputeras, $23 \%$ Chinese, $7 \%$ Indians, and $10 \%$ other races (BBC News, 2013). Because Malaysia is a multi-racial nation, the possible effect of this factor on performance is paramount. Prior studies in the Malaysia setting have consistently confirmed that non-Bumiputeras (mainly Chinese) students are higher performers than Bumiputera (mainly Malay) students (Azmi \& Harith, 2012; Azmi \& Mustafa, 2017; Othman, Nopiah, Asshaari, Razali, Osman, \& Ramli, 2009). Azmi and Harith (2012), in their study of assessing students' performance from different ethnic groups, found that the Chinese students performed much better than the Bumiputera students across different cognitive levels. Similarly, Othman et al. (2009) discovered that first-year engineering students with the Malaysian Higher School Certificate pre-university qualifications did better in their first-year results as compared to students with matriculation pre-university qualifications. Considering the fact that the majority of the Malaysian Higher School Certificate pre-university qualification students were Chinese and ethnic Malays dominated the matriculation pre-university qualification, this outcome indicated ethnicity as a driving force for academic performance. Hence, the following hypothesis is proposed:

\section{H2 : Ethnicity is related to academic performance.}

The secondary schools in Malaysia can be categorised into several types. These include Vocational College, MRSM, School of Arts, School of Sports, Cluster School, National Religious School, National Secondary School, Bestari Religion Secondary School, 
and Technical School. While each type of school has its strengths and weaknesses, their ultimate goal is similar.

In 2009, the Government of Malaysia first introduced the High Performance School and Cluster School, with the aim of uplifting the quality of the schools. These schools mainly accept excellent students and thus are expected to produce high-performing students. It is of major concern for some parents to send their children to these types of schools as some believe that these schools are better than other schools. For example, the Petaling Utama district education department receives more than thousand requests each year from parents to switch to the cluster and high achieving schools (The Star, 2017). Students are selected for these schools based on their achievement in a specific test in either primary school (Primary School Evaluation Test), or junior high school (Pentaksiran Tingkatan 3/PT3 results).

As admission to the university depends on post-secondary achievement, parents tend to plan their children's future by applying to various types of public secondary schools or private schools. Prior studies have argued that the type of school attended later influences the academic performance of the students at university (Banai \& Perin, 2016; Win \& Miller, 2005). Win and Miller's (2005) key finding is that high school type impacts the academic performance of students at university, beyond their own background characteristics. The results of the study showed that students from government-sponsored schools performed better than students from private schools. Further, Banai and Perin (2016) provided the support that different school types are associated differently with academic performance. The results suggested that high school-gymnasium students performed better at university compared with high school-vocational stream students. This may imply that gymnasium high schools are better at preparing their students for tertiary education as compared to vocational high schools. This scenario has suggested that students might perform better in their academics if they were enrolled in appropriate types of secondary school. Therefore, it is hypothesised that:

\section{H3 : Type of secondary school is related to academic performance.}

Education is a gift that offers someone the opportunity to transform his life and family. However, many bright and excellent students still find it difficult to pursue their studies due to the costs of education. In Malaysia, the cost of pursuing a bachelor's degree in private higher institutions ranges between RM75,000 and RM93,000 inclusive of programme fees and cost of living, while for a public institution, the cost average is around RM20,000 (NST Online, 2017). In view of expensive programme fees and increased living costs over the years, many third parties, such as companies and non-profit-organisations, offer monetary support for selected students to pursue their educational programmes. The monetary support may come in the form of scholarship, which students do not need to repay upon their graduation, or loans, which students are expected to pay in full or in part depending on their academic achievement. Examples of institutions offering scholarship in Malaysia include People's Trust Council, TELEKOM, Petronas, public service department, state foundation, and zakat institutions. By having a sponsorship, a student can reduce his/her student debt. Study shows that student debt is one of the most pressing economic issues in contemporary education (Dwyer, McCloud, \& Hodson, 2012), which can be related to illness, stress, worry over debt, and financial problems (Richardson \& Elliott, 2011). Having such pressure might lead to underperformance or failure in a degree programme. Therefore, it is hypothesised that: 


\section{H4 : Education sponsorship is related to academic performance.}

Family income is another source of financial support for students to pursue their tertiary education. Data from the Department of Statistics Malaysia showed that the mean and median of Malaysian income in 2016 were RM6,958 and RM5,228, respectively. The income was generated mainly from four common sources: paid employment, self-employed, property and investment, and current transfer received. The data further reported that five of ten households earn RM5,228 or less in a month. Breaking down the income into the household group (Table 1) showed that the T20 group has an average of RM16,088 per month, followed by the M40 group with a mean of RM6,502 per month. The B40 group, on the other hand, had an average income of RM2,848 per month. This data indicates that the majority of Malaysian are able to help finance their children in pursuing their educations.

Table 1: Malaysian household income 2016

\begin{tabular}{crrr}
\hline Group & Income share (\%) & Median & Mean $(\mathbf{R M )}$ \\
\hline B40 & 16.4 & 3,000 & 2,848 \\
M40 & 37.4 & 6,275 & 6,502 \\
T20 & 47.2 & 13,148 & 16,088 \\
\hline
\end{tabular}

Source: Department of Statistics Malaysia

Previous studies have found that family income does influence student achievement. For example, An (2010) discovered that economic investments made by parents were positively associated with their child's educational attainment. This suggests that parents with higher earnings are more capable of supporting the educational costs of their children. In such a case, students are expected to have a more conducive learning experience with a more manageable level of stress. This conducive situation may result in better achievement than students with financial stress. Baliyan, Rao, and Baliyan's (2012) study involving 168 students in Botswana revealed that family income level had a significant influence on the performance of students in maths. The finding indicates that high-level income parents were able to support the financial needs of their children, which, in turn, was related to better performance. In contrast, Adzido et al.'s (2016) study on tertiary education in Ghana discovered that family financial status was not an important predictor of the academic performance of students. A good number of respondents from low income families performed well as measured by their CGPA. This may infer that students who are diligent can overcome the impact of low income. Therefore, it is hypothesised that:

\section{H5 : Family income is related to academic performance. FINDINGS AND DISCUSSION}

The respondents of the study are the undergraduate students who had completed their accountancy degree programme at UUM in 2016. Specifically, 367 accounting students (male $=84$ and female $=283$ ) completed their studies in the specified year. The study uses a quantitative research design using secondary data obtained from the Academic Affairs Department, UUM. There are two accountancy programmes at UUM, namely, Bachelor of Accounting (Honours) [B.Acct.(Hons)] and Bachelor of Accounting (Information Systems) (Honours) [B.Acct.(IS)(Hons)]. All the available secondary data of the 367 graduates from 
both programmes were used for the analysis. The CGPA data represents the actual performance of the students in their four-year accountancy degree programme.

The IBM Statistical Package for the Social Sciences (Version 23) was used for the data analysis. The analysis tools used for analysis include the descriptive analysis (to calculate the frequencies of the graduates' profiles), the independent sample t-test, and the analysis of variance (ANOVA) with a post-hoc test. An independent sample t-test was carried out to compare the mean scores of two different groups of people or conditions. The ANOVA with a post-hoc test was used to compare the variance (variability in scores) between the different groups.

\section{Graduates' profiles}

The vast majority of the students were female at $77.11 \%$ of the sample and male at $22.89 \%$. Most were from B.Acct.(Hons) (71.93\%) and B.Acct.(IS) (Hons) (28.07\%) degree (Table 2). Malay students $(58.86 \%)$ dominated the programme, followed by Chinese $(34.33 \%)$ and Indian (5.99\%). Most of them graduated with the second class upper (59.40\%), followed by a first-class degree $(21.25 \%)$ and second class lower (19.35\%).

A high percentage of the graduates' parents $(71.12 \%)$ had an income below RM3,000, hence, falling in the B40 group. Forty graduates $(10.90 \%)$ were from families without an income. Only 66 graduates $(17.98 \%)$ were from families with a monthly income of more than RM3,000.

Table 2: Graduates' background

\begin{tabular}{lrrlrr}
\hline & No. & \% & & No. & \% \\
\hline Gender: & & & Type of secondary school: & & \\
Male & 84 & 22.89 & MRSM & 12 & 3.27 \\
Female & 283 & 77.11 & Religious Secondary School & 23 & 6.27 \\
Total & 367 & 100 & Boarding School & 8 & 2.18 \\
& & & Bestari Religion Secondary & & \\
& & & School & 5 & 1.36 \\
Ethnic group: & & & National Secondary School & 222 & 60.49 \\
Malay & 216 & 58.86 & Private Secondary School & 2 & .55 \\
Chinese & 126 & 34.33 & Technical School & 14 & 3.81 \\
India & 22 & 5.99 & School of Sports & 2 & .54 \\
Others & 3 & .82 & Not specified & 79 & 21.53 \\
Total & 367 & 100 & Total & 367 & 100 \\
& & & & & \\
Family income: & & & Programme: & 264 & 71.93 \\
No income & 40 & 10.90 & B.Acct.(Hons) & 103 & 28.07 \\
RM1 - RM3,000 (B40) & 261 & 71.12 & B.Acct.(IS)(Hons) & 367 & 100 \\
RM3,001 - RM7,000 (M40) & 59 & 16.07 & Total & & \\
More than RM7,000 (T20) & 7 & 1.91 & & 78 & 21.25 \\
Total & 367 & 100 & Class of Degree: & 218 & 59.40 \\
& & & First class & 71 & 19.35 \\
Sponsorship: & & & Second class upper & 367 & 100 \\
No sponsorship & 52 & 14.17 & Second class lower & & \\
With sponsorship & 315 & 85.83 & Total & & \\
Total & 367 & 100 & & &
\end{tabular}




\section{Factors affecting students' academic performance}

Inconsistent with Norwani and Yusof (2008), our study found no significant difference in the academic performance of male and female students (Table 3). Hypothesis 1 is, therefore, not supported. This finding is in line with Swope and Schmitt's (2006) study of the academic performance of economic majors at the U.S. Naval Academy (USNA) in which gender was not found as a significant predictor. A possible explanation for this finding is that the entry requirements set for students to pursue their studies in both B.Acct.(Hons) and B.Acct.(IS)(Hons) programmes are high, and they need to obtain at least 3.30 for the CGPA from all the channels of qualifications: (1) Malaysian Higher School Certificate, (2) Matriculation/UUM Foundation (pre-university), and (3) Diploma. Even though the minimum CGPA at the entry-level is $3.30,77.38 \%$ of the students had a CGPA of more than 3.70. A higher CGPA ensures that students are of high quality, academically rigorous, and have a positive attitude towards achieving high academic performance.

Table 3: T-test - Gender

\begin{tabular}{lrrrr}
\hline Variable & N & Mean & F & Sig \\
\hline CGPA & & & .772 & .380 \\
Male & 84 & 3.2582 & & \\
Female & 283 & 3.3175 & & \\
\hline
\end{tabular}

In relationship to ethnic groups, student performances varied amongst the three major ethnicities - the Malay, Chinese, and Indian ( $\mathrm{F}=96.871, p=.000)$ (Table 4), hence, supporting hypothesis 2 . Specifically, students' academic performance at the tertiary level was highest for Chinese students. The finding is consistent with other studies that found that Chinese students performed better than Malay and Indian students (Alfan \& Othman, 2005) and that Chinese students outperformed Bumiputeras (Azmi \& Harith, 2012).

Table 4: ANOVA test - Ethnicity

\begin{tabular}{lrrrr}
\hline Variable & N & Mean & F & Sig \\
\hline CGPA & & & 96.871 & $.000^{*}$ \\
Malay & 216 & 3.1285 & & \\
Chinese & 126 & 3.6156 & & \\
India & 22 & 3.2459 & & \\
Others & 3 & 3.2733 & & \\
\hline$* p<.01$ & & & &
\end{tabular}

A Tukey post-hoc test revealed that the Chinese students' academic performance was significantly different from that of Malay and Indian students, but not with that of other students (Table 5). However, there was no significant difference in the performance of Malay and Indian, and Malay and others. The study's finding, therefore, suggested that the Malay, Indian, and other students place less importance on excellence and thus lag behind Chinese students. Several factors that might contribute to Chinese students outperforming other students include practising the correct learning methods, establishing priorities at school and university, and learning in a small group to encourage brainstorming and time-savings (Utusan Online, 2001). Moreover, their parents are very strict about the education of their children and foster a sense of learning from childhood to make their children more 
disciplined (Utusan Online, 2001). Hence, the Malay, Indian, and other students should expend more effort to improve their academic performance to be on par with their Chinese counterparts.

Table 5: Post-hoc test - Ethnicity

\begin{tabular}{llr}
\hline Race & Race & Sig \\
\hline Malay & Chinese & $.000^{*}$ \\
& Indian & .170 \\
& Others & .764 \\
Chinese & Malay & $.000^{*}$ \\
& Indian & $.000^{*}$ \\
& Others & .101 \\
Indian & Malay & .170 \\
& Chinese & $.000^{*}$ \\
& Others & .998 \\
Others & Malay & .764 \\
& Chinese & .101 \\
& Indian & .998 \\
\hline$* p<.01$ & &
\end{tabular}

Earlier studies (Akinloye, Adu, \& Adu, 2017; Banai \& Perin, 2016; Win \& Miller, 2005) provided the support that different school types associated differently with academic performance. Win and Miller (2005), for instance, found that government school students performed better than private school students. In contrast, Akinloye et al. (2017) found that students in private schools performed better than their counterparts in public schools.

In the present study, more than half of the accounting graduates were enrolled in national secondary schools $(60.49 \%)$ during their secondary school studies (Table 2). Others included religious secondary school (6.27\%), technical school (3.81\%), and MRSM (3.27\%), while only $.55 \%$ of them were from private schools. An ANOVA test was carried out to test the effect of these types of secondary school on the students' academic performance (Table 6). The findings indicated a statistically significant difference in the relationship between the type of secondary school and academic performance $(\mathrm{F}=4.750, p=.000)$. Hypothesis 3 is, therefore, supported.

Table 6: ANOVA test - Type of secondary school

\begin{tabular}{lrrrr}
\hline Variable & N & Mean & F & Sig \\
\hline CGPA & & & 4.750 & $.000^{*}$ \\
National Secondary School & 222 & 3.3104 & & \\
Fully Residential School/Boarding School & 8 & 2.9313 & \\
MRSM & 12 & 3.1808 & \\
Religious Secondary School & 23 & 3.0987 & \\
Private Secondary School & 2 & 3.5550 & \\
Technical School & 14 & 3.0650 & \\
Bestari Religion Secondary School & 5 & 3.5720 & \\
School of Sports & 2 & 3.6250 & \\
$* p<.01$ & & &
\end{tabular}

A Tukey post-hoc test revealed that the students' academic performance from national secondary school was significantly different from that of boarding school and religious secondary school (Table 7). The findings indicated that students from national secondary 
schools performed better than students from boarding schools and religious secondary schools. In addition, the academic performance of students from bestari religion secondary schools was significantly different from religious secondary schools, boarding schools, and technical schools, wherein bestari religion secondary school students performed better than these groups.

Table 7: Post-hoc test - Type of secondary school

\begin{tabular}{|c|c|c|}
\hline Type of secondary school & Type of secondary school & Sig \\
\hline \multirow[t]{7}{*}{ National Secondary School } & Boarding School & $.028 *$ \\
\hline & MRSM & .880 \\
\hline & Religious Secondary School & $.062 * *$ \\
\hline & Private Secondary School & .964 \\
\hline & Technical School & .114 \\
\hline & Bestari Religion Secondary School & .633 \\
\hline & School of Sports & .872 \\
\hline \multirow[t]{7}{*}{ Boarding School } & National Secondary School & $.028 *$ \\
\hline & MRSM & 697 \\
\hline & Religious Secondary School & .914 \\
\hline & Private Secondary School & .231 \\
\hline & Technical School & .983 \\
\hline & Bestari Religion Secondary School & $.014 *$ \\
\hline & School of Sports & .126 \\
\hline \multirow[t]{7}{*}{ MRSM } & National Secondary School & .880 \\
\hline & Boarding School & 697 \\
\hline & Religious Secondary School & .997 \\
\hline & Private Secondary School & .802 \\
\hline & Technical School & .985 \\
\hline & Bestari Religion Secondary School & .318 \\
\hline & School of Sports & .626 \\
\hline \multirow[t]{7}{*}{ Religious Secondary School } & National Secondary School & $.062 * *$ \\
\hline & Boarding School & .914 \\
\hline & MRSM & .997 \\
\hline & Private Secondary School & .547 \\
\hline & Technical School & 1.000 \\
\hline & Bestari Religion Secondary School & $.066 * *$ \\
\hline & School of Sports & .355 \\
\hline \multirow[t]{7}{*}{ Private Secondary School } & National Secondary School & .964 \\
\hline & Boarding School & .231 \\
\hline & MRSM & .802 \\
\hline & Religious Secondary School & .547 \\
\hline & Technical School & .486 \\
\hline & Bestari Religion Secondary School & 1.000 \\
\hline & School of Sports & 1.000 \\
\hline \multirow[t]{7}{*}{ Technical School } & National Secondary School & .114 \\
\hline & Boarding School & .983 \\
\hline & MRSM & .985 \\
\hline & Religious Secondary School & 1.000 \\
\hline & Private Secondary School & .486 \\
\hline & Bestari Religion Secondary School & $.059 * *$ \\
\hline & School of Sports & .307 \\
\hline Bestari Religion Secondary School & National Secondary School & .633 \\
\hline
\end{tabular}




\begin{tabular}{llr}
\hline Type of secondary school & Type of secondary school & Sig \\
\hline & Boarding School & $.014^{*}$ \\
& MRSM & .318 \\
& Religious Secondary School & $.066^{* *}$ \\
& Private Secondary School & 1.000 \\
& Technical School & $.059 * *$ \\
& School of Sports & 1.000 \\
School of Sports & National Secondary School & .872 \\
& Boarding School & .126 \\
& MRSM & .626 \\
& Religious Secondary School & .355 \\
& Private Secondary School & 1.000 \\
& Technical School & .307 \\
& Bestari Religion Secondary School & 1.000 \\
\hline
\end{tabular}

$* p<.05 ; * * p<.10$

Krishnapillai, Kwok, Cheong, Xin, Cheong, and Lee (2016) discovered that school characteristics, such as quality of schools, affect parents' preferences in selecting the secondary school for their children. Win and Miller (2005), however, argued that agreement had not been reached on the reasons for differences in the academic performance of students from different types of school. Marks, McMillan, and Hillman (2001) argued that students' confidence level, schools with a more conducive learning environment, and parental aspirations for the students' education contribute to student achievement. Bakri, Razak, Rahman, and Khalid (2005), on the other hand, noted five factors that lead to the poor academic performance of students. These factors are learning techniques (e.g., poor time management, depends entirely on lecturer lecture notes), student attitudes (e.g., they are not ambitious and just learn to pass the examinations), communication, interest, and motivation (e.g., less confident with the courses taken), spiritual (e.g., easy to give up with failure), and students self-confidence (e.g., students dissatisfied with their achievements).

Funding for pursuing study in higher education colleges and universities is critical for students, especially those who come from middle- and lower-income families. Educational funding comes from various sources, such as government, private agencies, and even parental income. In the present study, most of the graduates received sponsorships (85.83\%) to support themselves financially. Most sponsorships (82.83\%) were from the National Higher Education Fund Corporation, a financing scheme established by the government to provide education financing for students in local institutions. Fifty-two graduates $(14.17 \%)$, on the other hand, did not receive any sponsorship.

Table 8: T-test - Sponsorship

\begin{tabular}{lllll}
\hline Variable & N & Mean & F & Sig \\
\hline CGPA & & & .765 & .365 \\
No sponsorship & 52 & 3.3375 & & \\
With sponsorship & 315 & 3.2984 & & \\
\hline
\end{tabular}

A t-test was conducted to explore the effect of the sponsorship on academic performance (Table 8) where participants were categorised into two groups: with sponsorship or without sponsorship. The t-test revealed that no difference existed in terms of the academic performance of students between the groups. Hypothesis 4 is, therefore, not supported. A 
plausible reason for this finding is that good and quality students (with high CGPA screened at the entry requirements) would achieve high academic performance regardless of the availability of the sponsorship. This is because they have better study habits, work harder, and are more organised and diligent.

A review of literature has shown that many studies have supported a strong association between family income and academic performance of their children (An, 2010; Baliyan et al., 2012; Machebe, Ezegbe, \& Onuoha, 2017). Machebe et al. (2017), for instance, argued that greater academic achievement for a student is accomplished by those students from families with strong financial well-being. This is because parents would be able to provide learning materials needed by their children (Machebe et al., 2017) and support the educational costs (An, 2010). Similarly, Baliyan et al. (2012), in their survey of students' performance in senior secondary school mathematics in Botswana, discovered that parent's income level was a significant predictor of the students' performance. Consistent with their findings, the present study discovered a statistically significant difference between family income and academic performance $(\mathrm{F}=3.274, p=.021)$ (Table 9), hence, supporting hypothesis 5 .

Table 9: ANOVA test - Family income

\begin{tabular}{lrrrr}
\hline Variable & N & Mean & F & Sig \\
\hline CGPA & & & 3.274 & $.021^{*}$ \\
No income & 40 & 3.2690 & & \\
$<$ RM3,000 (B40) & 261 & 3.3368 & & \\
RM3,001 - RM7,000 (M40) & 59 & 3.1905 & & \\
$>$ RM7,000 (T20) & 7 & 3.2343 & & \\
\hline$* p<.05$ & & & &
\end{tabular}

A Tukey post-hoc test revealed that the academic performance of students from B40 family was significantly different from the M40 family, but not with T20 and no income family (Table 10). The performance of B40 students was better than M40 students. It is important to note that more than two-thirds of the graduates covered in this study were from a low-income family (i.e., B40 group) with a monthly income of less than RM3,000. The finding is consistent with Adzido et al.'s (2016) study which discovered that students from low-income families performed well in their studies.

Table 10: Post-hoc test - Family income

\begin{tabular}{llr}
\hline Family income & Family income & Sig \\
\hline No income & B40 & .640 \\
& M40 & .669 \\
& T20 & .994 \\
B40 & No income & .640 \\
& M40 & $.015^{*}$ \\
& T20 & .858 \\
M40 & No income & .669 \\
& B40 & $.015^{*}$ \\
& T20 & .988 \\
T20 & No income & .994 \\
& B40 & .858 \\
& M40 & .988 \\
\hline
\end{tabular}




\section{$* p<.05$ \\ CONCLUSION, LIMITATIONS, AND IMPLICATIONS}

This study examined the effects of gender, ethnicity, type of secondary school, availability of education sponsorship, and family income on academic performance of 367 undergraduate accounting students at UUM. Academic performance was measured using the CGPA of students in their final semester of the programme. The findings demonstrated the importance of ethnicity, type of secondary school, and family income on academic performance. Nevertheless, no significant difference in students' academic performance was found based on gender or the availability of sponsorship.

Even though this study has many interesting findings to contribute to the literature, some features, however, limit the generalisability of these findings. First, this study has only focused on one institution and accounting graduates. Apart from the UUM, studies examining the same issue could be carried out across different institutions and study levels. Second, the factors influencing students' academic performance were limited to gender, ethnicity, type of secondary school, sponsorship, and family income. Therefore, some variables (e.g., entry qualification to university, CGPA for Degree entrance, and Malaysian University English Test or MUET band scores) that may have an influence over the students' performance in the university were omitted. Further research examining these factors on academic performance should be undertaken.

The study discovered that the Malay, Indian, and other students seem to lag behind Chinese students. Further research should, therefore, be carried out to determine the factors that could cause the difference in the performance amongst the races.

The outcome of this study could provide meaningful insight to both higher education providers and national education ministry in facilitating accounting students to extend their academic performance in higher institutions. The higher education providers could potentially identify and impose appropriate intervention programmes to the accounting students by taking into consideration selected demographic factors that are likely affecting student's academic performance. Identification of the intervention programmes may concentrate on factors that potentially have a substantial influence on explaining the performance variance amongst the accounting students. As reported in this study, factors involving ethnicity, prior academic exposure (the type of secondary school), and family financial status deserve special attention. Designing intervention programmes that specifically deal with the issues concern could be crucial in realigning the students' competencies with ever-increasing expectation in pursuing accounting programme in higher institutions. Hence, equipping students with relevant competencies and skills could assist them in sustaining their academic performance over the years in pursuing the accounting programme.

This study outcomes also provide meaningful input for policy making purpose, particularly to the Ministry of Education. The results have reported that prior education status does affect students' performance while undergoing their accounting programme at higher institutions. As reported, students obtained their secondary education in national secondary schools tend to better excel in their accounting degree programme. This would indicate that the environment in which students had obtained their secondary education has a certain effect in shaping the student's characteristics, mindset, attitude, and learning style. Hence, introducing any programmes that potentially strengthen students' personalities and attitude 
may be introduced in all types of schools. Early exposure to the students with appropriate skills and techniques, as well as setting the right mindset, do help to mould the students' ability to survive and to sustain their excellence in the higher education level.

\section{REFERENCES}

Adzido, R.Y.N., Dzogbede, O.E., Ahiave, E., \& Dorkpah, O.K. (2016). Assessment of family income on academic performance of tertiary students: The case of Ho Polytechnic, Ghana. International Journal of Academic Research in Accounting, Finance and Management Sciences, 6(3).

Ahmad, M.R., Pervaiz, M.K., \& Aleem, M. (2015). A comparative study of the factors affecting the male and female students' achievement performance in higher education (A case of government college university, Lahore. European Scientific Journal, 11(7), 429-436.

Aidoo-Buameh, J., \& Ayagre, P. (2013). The effect of entry grades on academic performance of university accounting students: A case of undergraduates of Central University. Research Journal of Finance and Accounting, 4(7), 198-206.

Akinloye, G.M., Adu, K.O., \& Adu, E.O. (2017). A comparative analysis of students' performance in economics in private and public secondary schools in Lagos State, Nigeria. Journal of Social Sciences, 44(2-3), 144-151.

Alfan, E., \& Othman, N. (2005). Undergraduate students' performance: The case of University of Malaya. Quality Assurance in Education, 13(4), 329-343.

Ali, M., \& Hayat, B. (2019). Non-academic factors influencing students' achievement: a study in the Indonesian madrasahs. International Journal of Learning and Intellectual Capital, 16(2), 180192.

An, B.P. (2010). The relations between race, family characteristics, and where students apply to college. Social Science Research, 39, 310-323

Azmi, A.A.C., \& Mustapha, M.Z. (2017). The role of competitiveness, gender and ethnicity in influencing academic performance. MOJEM: Malaysian Online Journal of Educational Management, 2(1), 37-47.

Azmi, A.C. \& Harith, S. (2012). Higher order cognitive skills and performance of undergraduate students: Do these skills differ among Asian groups? Far East Journal of Psychology and Business, 9(3), 19-28.

Bakri, N., Razak, N.Z.A., Rahman, H.A., \& Khalid, A.A. (2005). Punca prestasi pembelajaran yang lemah di kalangan pelajar Fakulti Pengurusan dan Pembangunan Sumber Manusia, Universiti Teknologi Malaysia, Skudai, Johor. Jurnal Teknologi, 43, 29-44.

Baliyan, S.P., Rao, K.S.M., \& Baliyan, P.S. (2012). Influence of parental education and income level on students' performance in senior secondary school mathematics in Botswana. Global Research Journal on Mathematics and Science Education, 1(2), 135-158.

Banai, B. \& Perin, V. (2016). Type of high school predicts academic performance at university better than individual differences. PLOS ONE, 11(10), 1-16. 
BBC News (2013). Is Malaysia university entry a level playing field? Retrieved from http://www.bbc.com/news/world-asia-23841888

Byrne, M., \& Flood, B. (2008). Examining the relationships among background variables and academic performance of first year accounting students at an Irish University. Journal of Accounting Education, 26, 202-212.

Conard, M.A. (2006). Aptitude is not enough: How personality and behaviour predict academic performance. Journal of Research in Personality, 40(3), 339-346.

Dwyer, R.E., McCloud, L., \& Hodson, R. (2012). Debt and graduation from American universities. Social Forces, 90(4), 1133-1155.

Farooq, M.S., Chaudhry, A.H., Shafiq, M., \& Berhanu, G. (2011). Factors affecting students' quality of academic performance: A case of secondary school level. Journal of Quality and Technology Management, 7(2), 1-14.

Ghazvini, S.D., \& Khajehpour, M. (2011). Gender differences in factors affecting academic performance of high school students. Procedia - Social and Behavioral Sciences, 15, 10401045.

Goff, M. \& Ackerman, P. L. (1992). Personality-intelligence relations: Assessment of typical intellectual engagement. Journal of Educational Psychology, 84(4), 537-552.

Kamal, P., \& Ahuja, S. (2019). Academic performance prediction using data mining techniques: Identification of influential factors effecting the academic performance in undergrad professional course. In Harmony Search and Nature Inspired Optimization Algorithms (pp. 835-843). Springer, Singapore.

Krishnapillai, G., Kwok, S. Y., Cheong, P., Xin, L., Cheong, K. K., \& Lee, Y. (2016). Secondary school choice-what do parents concern?. International Business Education JournalIBEJ, 9(1), 66-77.

Kumwenda, B., Cleland, J.A., Walker, K., Lee, A.J., \& Greatrix, R. (2017). The relationship between school type and academic performance at medical school: A national, multi-cohort study. BMJ Open, 7(8), 1-11.

Lam, S.F., Jimerson, S., Kikas, E., Cefai, C., Veiga, F.H., Nelson, B., Zollneritsch, J. (2012). Do girls and boys perceive themselves as equally engaged in school? The results of an international study from 12 countries. Journal of School Psychology, 50(1), 77-94. Retrieved from https://doi.org/10.1016/j.jsp.2011.07.004

Machebe, C.H., Ezegbe, B.N., \& Onuoha, J. (2017). The impact of parental level of income on students' academic performance in high school in Japan. Universal Journal of Educational Research, 5(9), 1614-1620.

Marks, G., McMillan, J., \& Hillman, K. (2001). Tertiary entrance performance: The role of student background and school factors. Longitudinal Surveys of Australian Youth. Research Report No. 22. Victoria: Australian Council for Educational Research. Retrieved from https://research.acer.edu.au/cgi/viewcontent.cgi?article=1023\&context=lsay_research

Ministry of Higher Education Malaysia. High performance schools. Retrieved from https://moe.gov.my/index.php/en/soal-selidik/183-murid-pelajar/sekolah/1574-sekolahberpretasi-tinggi 
MOHE (2015). MOHE graduate traser study. Retrieved from http://graduan.mohe.gov.my/Mainpage2.html

Ngozi, M. (2011). Relationship between gender and university students' academic performance in arts-related subjects. Gender \& Behaviour, 9(1), 3701-3710.

Norwani, N.M., \& Yusof, R. (2008). Factors influencing academic achievement among business adminıstration students of public higher learnıng 1nstitutions (PHLIS). International Business Education Journal (IBEJ), 1, 1-13.

NST Online (2017). How much would it cost to pursue higher education in Malaysia? Retrieved from https://www.nst.com.my/news/2017/03/223461/how-much-would-it-cost-pursue-highereducation-malaysia

NST Online (2015). Malaysia needs 60,000 accountants by 2020. Retrieved from https://www.nst.com.my/news/2015/09/malaysia-needs-60000-accountants-2020

Olufemioladebinu, T., Adediran, A.A., \& Oyediran, W.O. (2018). Factors influencing the academic achievement of students' in Colleges of Education in Southwest, Nigeria. Journal of Education and Human Development, 7(3), 109-115.

Othman, H., Nopiah, Z.M., Asshaari, I., Razali, N., Osman, M.H., \& Ramli, N. (2009). A comparative study of engineering students on their pre-university results with their FirstYear performance $F K A B, U K M$. Paper presented at the Seminar Pendidikan Kejuruteraan Kongres Pengajaran dan Alam Bina (PeKA'09) dan Pembelajaran UKM 2009, UKM.

Richardson, T. \& Elliott, P. (2011). On tuition fees, student debt and mental health. Psychologist, 24(1), 6 .

Swope, K.J. \& Schmitt, P.M. (2006). The performances of economics graduates over the entire curriculum: The determinants of success. The Journal of Economic Education, 37(4), 387394.

The Star (2017). What the authorities say. Retrieved from https://www.thestar.com.my/news/education/2016/04/17/what-the-authoritiessay/\#A7ScHOyeEMOJgW44.99

Utusan Online (2001). Rahsia kejayaan pelajar bukan Melayu. Retrieved from http://ww1.utusan.com.my/utusan/info.asp?y=2001\&dt=0718\&pub=Utusan_Malaysia\&sec=L aporan_Khas\&pg=lk_04.htm

Win, R. \& Miller, P. (2005). The effects of individual and school factors on university students' academic performance. Perth: The Centre for Labour Market Research. The University of Western Australia. Retrieved from http://citeseerx.ist.psu.edu/viewdoc/download? doi=10.1.1.196.1010\&rep=rep1\&type $=$ pdf 